\title{
Meis1 Is Required for c-Met Inhibition to Suppress Cell Proliferation of Skin Squamous Cell Carcinoma Cells
}

\author{
Megumi Saito, Kazuhiro Okumura, Yasuhiro Yoshizawa, Haruka Munakata, Eriko Isogai, \\ Yuichi Wakabayashi \\ Department of Carcinogenesis Research, Division of Experimental Animal Research, Chiba Cancer Center \\ Research Institute, Chiba, Japan \\ Email: yuichi_wakabayashi@chiba-cc.jp
}

Received 7 June 2016; accepted 8 July 2016; published 11 July 2016

Copyright (C) 2016 by authors and Scientific Research Publishing Inc.

This work is licensed under the Creative Commons Attribution International License (CC BY). http://creativecommons.org/licenses/by/4.0/

\section{(c) (i) Open Access}

\begin{abstract}
Previous studies have shown that Meis1 plays an important role in the pathogenesis of acute myeloid leukemia (AML) and acute lymphoblastic leukemia (ALL). Meis1 belongs to the TALE family, the members of which are used as biomarkers for AML. Meis1 has been shown to play a functional role in epithelial tissues, such as skin. However, its functions in skin carcinogenesis remain poorly understood. On the other hand, the c-Met inhibitor SU11274 has been identified through drug screening with HOXA9/Meis1-induced AML cell lines. SU11274 altered cell proliferation and the cell cycle status in human AML cell lines. Thus, we hypothesized that the effects of SU11274 are dependent on Meis1 and that its knockdown may diminish the effects of SU11274 not only in AML cell lines, but also in skin cancer cell lines. In order to test our hypothesis, we established Meis1 knockdown cell lines using two skin squamous cell carcinoma cell lines (B9 and D3) and treated these cell lines with SU11274. The results obtained showed that SU11274 suppressed cell proliferation by modulating cell cycle progression in the presence of Meis1, but not in its absence. Furthermore, an expression analysis showed that SU11274 activated the transcription of Meis1, which led to the transcription of Hif1 $\alpha$ and Cdkn2a (p16Ink4a and p19Arf). These results suggest that Meis1 is required for the c-Met inhibitor SU11274 to suppress the proliferation of the skin squamous cell carcinoma cell lines.
\end{abstract}

\section{Keywords}

Meis1, c-Met, Skin Squamous Cell Carcinoma

How to cite this paper: Saito, M., Okumura, K., Yoshizawa, Y., Munakata, H., Isogai, E. and Wakabayashi, Y. (2016) Meis1 Is Required for c-Met Inhibition to Suppress Cell Proliferation of Skin Squamous Cell Carcinoma Cells. Journal of Biosciences and Medicines, 4, 53-65. http://dx.doi.org/10.4236/jbm.2016.47007 


\section{Introduction}

Meis1 (myeloid ecotropic insertion site 1) is a member of the TALE (three amino acid loop extension) family of homeodomain transcription factors, which interact with Hox transcription factors and promote the expression of their target genes [1]-[3]. These interactions functionally incorporate Meis1 into a range of Hox-dependent developmental programs [4]. The expression of HOXA9 and Meis1 is frequently up-regulated in primary acute myeloid leukemia (AML) and acute lymphoblastic leukemia (ALL) [5] [6]. Research into the potential of HOX and TALE genes to act as biomarkers of AML are currently ongoing, and correlations with responses to chemotherapy have already been reported [7]-[9]. As in leukemia, gene expression studies in lung adenocarcinomas [10], neuroblastomas [11]-[13], ovarian carcinomas [14], and nephroblastomas [15] have shown that the expression of Meis1 is up-regulated in tumor tissues, which is suggestive of an oncogenic role. A previous study indicated that Meis1 is required for skin tumorigenesis in a mouse model [16]. However, the mechanisms underlying the functions of Meis1 in skin tumorigenesis remain poorly understood. On the other hand, several studies have suggested that Meis1 plays a functional role in several tissues, such as hematopoietic stem cells (HSCs) [17], cardiomyocytes [18], lung cancer cell lines [19], thymus [20] and skin [16]. These findings suggest that Meis1 exerts anti-proliferative effects as well as oncogenic activities, and has complex roles in cell proliferation, which may depend on the cellular context.

Several studies have indicated that Meis1 transcriptionally activates Hif1 $\alpha$ and Cdkn2a (p16Ink4a and p19Arf) in long-term HSCs (LT-HSCs) and cardiomyocytes, respectively [18] [21]. Hif1 $\alpha$ is a major transcriptional regulator of hypoxic responses and Meis1 activates Hif1 $\alpha$ to inhibit the generation of reactive oxygen species (ROS) in HSCs [22]-[24]. The Cdkn2a locus encodes two separate proteins (Cdkn2a, also known as p16Ink4a and p19Arf) generated from alternative open reading frames. Cdkn2a (p16Ink4a and p19Arf) has been identified as a tumor suppressor, which belongs to the cyclin-dependent kinase inhibitor family and induces cell cycle arrest, apoptosis, and senescence [25] [26]. Furthermore, several studies showed that papilloma growth and squamous cell carcinoma incidence were markedly increased in Cdkn2a (p16Ink4a and p19Arf)-deficient mice using the two-stage chemically induced skin carcinogenesis protocol [27] [28]. Hif1 $\alpha$ and Cdkn2a (p16Ink4a and p19Arf) play important roles in tumor suppression in this manner.

Previously, a pyrrole indolinone compound, SU11274, that targets the ATP-binding site of c-Met was shown to block HGF-dependent c-Met activation [29]. The c-Met inhibitor SU11274 has been identified through candidate drug screening using Meis1/HoxA9-induced AML cell lines. SU11274 was found to decrease cell proliferation and alter the cell cycle in human AML cell lines [30]. In other cases, SU11274 has been shown to reduce cell viability in vitro in a number of cancers including glioblastoma, lung cancer, and melanoma [31]-[33]. Therefore, we tested the hypothesis that the effects of SU11274 are dependent on Meis1 and that its knockdown may diminish the effects of SU11274 in skin cancer cell lines.

\section{Materials and Methods}

\subsection{Short Hairpin RNAs (shRNAs)}

Meis1 shRNAs were generated using the pSUPER shRNA system (Oligo Engine) in accordance with the manufacturer's protocol. shRNA sequences were selected as previously described [19] [34]. The forward oligo was synthesized with the Bgl II end. The reverse oligo was synthesized with the Hind III end. The primer sequences are listed in Table 1. The annealed oligos were cloned into the pSUPER retro vector.

\subsection{Cell Culture and Retro Virus Infection}

The squamous cell carcinoma cell line (B9) and the spindle cell squamous cell carcinoma cell line (D3) were provided by Dr. Allan Balmain and cultured in Dulbecco's Modified Eagle's Medium (DMEM) (Sigma) containing 10\% Fetal Bovine Serum (FBS) (CCB) and 1\% Penicillin-Streptomycin Mixed Solution (Nacalai Tesque). PlatE ecotropic packaging cells were transfected with the control pSUPER-puro vector (6 $\mu \mathrm{g})$ or Meis1 shRNA vector $(6 \mu \mathrm{g})$ using the FuGENE ${ }^{\circledR} 6$ Transfection Reagent (Promega) in accordance with the manufacturer's recommendation. The retrovirus-containing medium was collected 48 hours after transfection and supplemented with $4 \mu \mathrm{g} / \mathrm{mL}$ polybrene (MILLIPORE) into B9 and D3 cells. Infected cells were selected for 2 weeks in the presence of $2 \mu \mathrm{g} / \mathrm{mL}$ puromycin. 
Table 1. Primer sequences used for shRNA and qRT-PCR.

\begin{tabular}{ccc}
\hline Gene & Forward primer & Reverse primer \\
Meis1 & GATCCCCGGATAACTTGATGA & AGCTTAAAAAGGATAACTTGA \\
shRNA1 & TTCAATTCAAGAGATTGAATC & TGATTCAATCTCTTGAATTGAA \\
& TCATCAAGTTATCCGGG \\
Meis1 & GATCCCCGCTCAGTAGCTTAA & AGCTTAAAAAGCTCAGTAGCTT \\
shNA2 & GGGAATTCAAGAGATTCCCTT & AAGGGAATCTCTTGAATTCCCTT \\
Meis 1 & AAGCTACTGAGCTTTTA & AAGCTACTGAGCGGG \\
Hif1 $\alpha$ & GCACAGGTGACGATGATGAC & TCCGGGCATTAATAAACCAA \\
$p 16^{I N K 4 a}$ & CGGCGAGAACGAGAAGAA & AAACTTCAGACTCTTTGCTTCG \\
$p 19^{A r f}$ & CCGCTGCAGACAGACTGG & ATCGGGGTACGACCGAAA G \\
Actb & GTCGCAGGTTCTTGGTCACT & GCCCTCTTCTCAAGATCCTCT \\
\hline
\end{tabular}

\section{3. c-Met Inhibitor Treatment}

SU11274 (Sigma) was dissolved in dimethyl sulfoxide (DMSO) at a concentration of $80 \mu \mathrm{M}$ and stored at $-20^{\circ} \mathrm{C}$. Cells were treated with SU11274 (Sigma) at a concentration of $1 \mu \mathrm{M}$ or $10 \mu \mathrm{M}$. DMSO (0.01\%) was used as a control.

\subsection{Cell Viability Assay (XTT Assay)}

Cell viability was determined using the XTT assay with Cell Proliferation Kit 2 (XTT) in accordance with the manufacturer's protocol (Roche). Approximately 1000 cells were seeded in each well of a 96-well culture plate. The XTT assay solution was added to the plate at 18, 42, 66, and 90 hours and incubated for 6 hours each time. Absorbance was measured at $450 \mathrm{~nm}$ using a $2030 \mathrm{ARVO}^{\mathrm{TM}} \mathrm{X}$ multilabel reader (Perkin Elmer).

\section{5. qRT-PCR}

Total RNA was isolated from the indicated cells using TRIzol (Invitrogen) in accordance with the manufacturer's protocol. cDNA was generated with the iScript ${ }^{\mathrm{TM}}$ Select cDNA Synthesis Kit (Bio-Rad) using $100 \mathrm{ng}$ of DNase-pretreated total RNA. qRT-PCR was performed using SsoFast ${ }^{\mathrm{TM}}$ EvaGreen $^{\circledR}$ Supermix With Low ROX in accordance with the manufacturer's protocol (Bio-Rad). mRNA expression levels were determined using the Applied Biosystems ${ }^{\circledR} 7500$ (Life Technologies) and normalized to the levels of $\beta$-Actin. The primer sequences used are listed in Table 1.

\subsection{Cell Cycle Analysis}

Cells were cultured for 96 hours after being treated (DMSO or c-Met inhibitor; $1 \mu \mathrm{M}, 10 \mu \mathrm{M}$ ). They were then collected and fixed in $70 \%$ ethanol at $4^{\circ} \mathrm{C}$ for $30 \mathrm{~min}$. The fixed cells were stained with propidium iodide (50 $\mu \mathrm{g} / \mathrm{mL}$ ) containing $200 \mu \mathrm{g}$ of RNase $\mathrm{A} / \mathrm{mL}$ and $1 \%$ Triton at $37^{\circ} \mathrm{C}$ for $40 \mathrm{~min}$. A flow cytometric analysis was conducted with JSAN (Japan-made sorter, analyzer) (Bay Bioscience). Approximately $1.0 \times 10^{5}$ cells were scanned to analyze the DNA content. Necrotic cells were excluded and the percentage of cells in the $G_{1}, S$, and $\mathrm{G}_{2} / \mathrm{M}$ phases of the cell cycle was determined.

\subsection{Statistical Analysis}

A total of at least three replicates were performed for all of the experiments. The significance of differences was calculated using the unpaired one and two-tailed Student's $t$-tests by yst at 2000. A $P$-value $<0.05$ was considered significant and that $<0.01$ highly significant.

\section{Results}

\subsection{Knockdown of Meis1 Increases the Proliferation of B9 and D3 Cells}

In order to investigate the role of Meis1 in cells, we utilized short hairpin RNAs (shRNAs) to repress the ex- 
pression of endogenous Meis1 in the skin squamous cell carcinoma cell line, B9 and the skin spindle cell squamous cell carcinoma cell line, D3 cells. B9 and D3 cells were transduced with retroviral vectors expressing shRNAs to specifically silence Meis1. The results of the qRT-PCR analysis showed that the mRNA expression levels of Meis1 were reduced significantly more by Meis1 shRNA1 and shRNA2 (B9: Meis1 shRNA1; $P=$ 0.0176, shRNA2; $P=0.0128$, D3: Meis1 shRNA1; $P=0.000454$, shRNA2; $P=0.000245$ ) than by the control vector (pSUPER) (Figure 1(a), Figure 1(b)). Several studies have indicated that Meis1 activates the transcription of Hif1 $\alpha$ and Cdkn2a ( $p 16^{\text {Ink4a }}$ and $p 19^{A r f}$ ) [18] [23]. Therefore, we examined the mRNA expression levels of Hif1 $\alpha$ and $C d k n 2 a\left(p 16^{\text {Ink4a }}\right.$ and $\left.p 19^{A r f}\right)$ using qRT-PCR. The results obtained showed that the mRNA levels of these genes were also significantly decreased after silencing the expression of Meis1 by Meis1 shRNA1 and

(a)

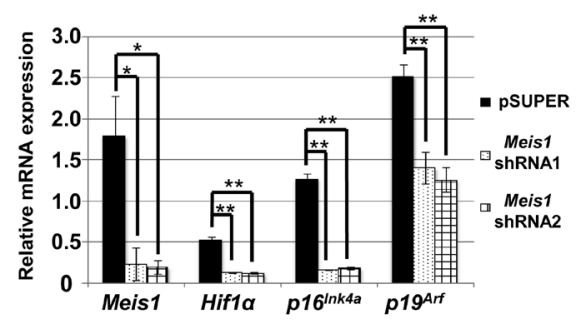

(c)

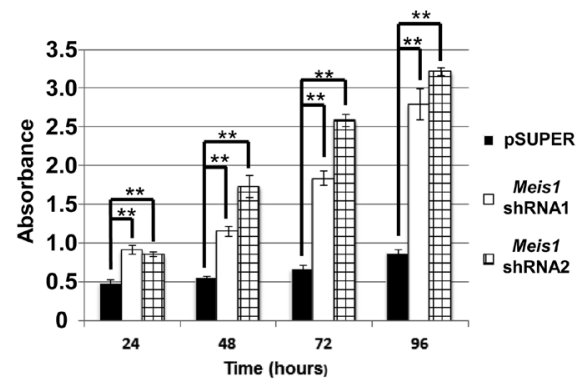

(e)

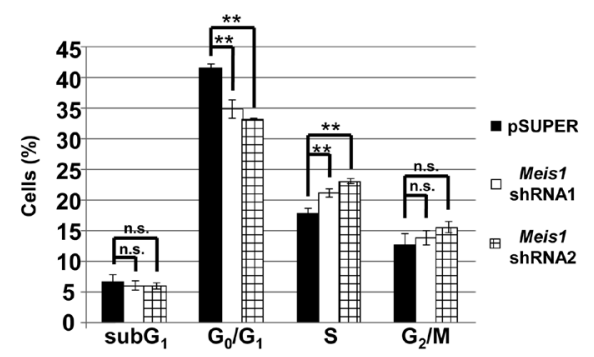

(b)

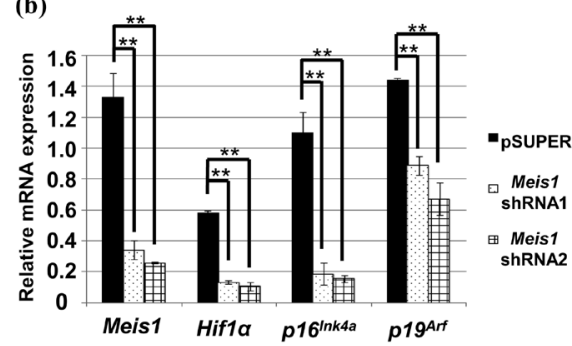

(d)

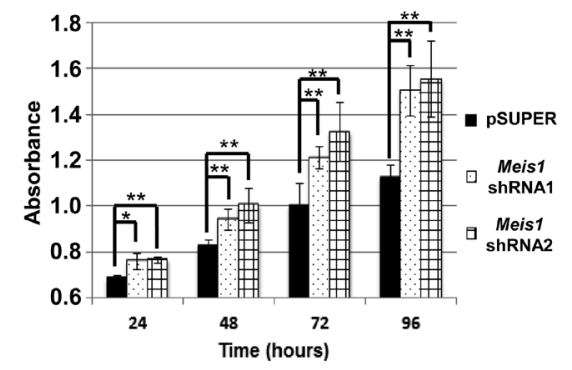

(f)

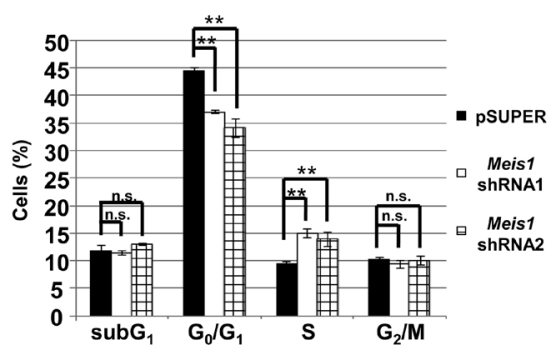

Figure 1. Meis1 regulates the proliferation of squamous cell carcinoma cells. (a) The relativemRNA levels of Meis1, Hif1 $\alpha$, $p 16^{I N K 4 a}$, and $p 19^{A r f}$ in B9 cells transduced with a control vector (pSUPER) (black), Meis1 shRNA1 (dotted), and Meis1 shRNA2 (latticed) were examined by qRT-PCR. (b) The relativemRNA levels of Meis1, Hif1 $\alpha, p 16^{I N K 4 a}$, and $p 19^{\text {Arf }}$ in D3 cells transduced with a control vector (pSUPER) (black), Meis1 shRNA1 (dotted), and Meis1 shRNA2 (latticed) were examined by qRT-PCR. (c) The viability of B9 cells transduced with a control vector (pSUPER) (black), Meis1 shRNA1 (dotted), and Meis1 shRNA2 (latticed) was examinedusing the XTT assay. Absorbance at $450 \mathrm{~nm}$ was plotted. (d) The viability of D3 cells transduced with a control vector (pSUPER) (black), Meis1 shRNA1 (dotted), and Meis1 shRNA2 (latticed) was examinedusing the XTT assay. Absorbance at $450 \mathrm{~nm}$ was plotted. (e) B9 cells transduced with a control vector (pSUPER) (black), Meis1 shRNA1 (dotted), and Meis1 shRNA2 (latticed) were subjected to the cell cycle analysis. (f) D3 cells transduced with a control vector (pSUPER) (black), Meis1 shRNA1 (dotted), and Meis1 shRNA2 (latticed) were subjected to the cell cycle analysis. For all the graphs, experiments were performed in triplicate. The $P$-value was calculated by the $t$-test and displayed as the mean $\pm \mathrm{SD}, \mathrm{n}=3$. Error bars represent $\mathrm{SD}$; standard deviation. ${ }^{* *}: P<0.01,{ }^{*}: P<0.05$. 
shRNA2 (B9: Hif1 $\alpha$ : Meis1 shRNA1; $P=2.58 \mathrm{E}-05$, shRNA2; $P=2.50 \mathrm{E}-05 ; p^{\text {Ink4a }}$ : Meis1 shRNA1; $P=$ 9.60E-06, shRNA2; $P=1.14 \mathrm{E}-05 ; p 19^{\text {Arf }}$ : Meis1 shRNA1; $P=0.00129$, shRNA2; $P=0.000247$, D3: Hif1 $\alpha$ : $P$ Meis1 shRNA1; $P=3.79-E-07$, shRNA2; $P=1.28 \mathrm{E}-05 ; p 16^{\text {Ink4a }}$ : Meis1 shRNA1; $P=0.000472$, shRNA2; $P$ $=0.000243 ; p 19^{\text {Arf }}$ : Meis1 shRNA1; $P=9.33 \mathrm{E}-05$, shRNA2; $P=8.57 \mathrm{E}-07$ ) in B9 and D3 cells (Figure $1(\mathrm{a})$, Figure 1(b)).

Cell viability was determined using the XTT assay in order to examine whether the knockdown of Meis1 affects the proliferation of B9 and D3 cells. The results showed that two different Meis1 shRNAs significantly increased the proliferative rate of B9 and D3 cells (B9: 24 hours: Meis1 shRNA1; $P=0.000286$, shRNA2; $P=$ 0.000142; 48 hours: Meis1 shRNA1; $P=0.000128$, shRNA2; $P=0.000138 ; 72$ hours: Meis1 shRNA1; $P=$ 0.3.59E-05, shRNA2; $P=3.22 \mathrm{E}-06$; 96 hours: Meis1 shRNA1; $P=7.85 \mathrm{E}-05$, shRNA2; $P=3.02 \mathrm{E}-07$, D3: 24 hours: Meis1 shRNA1; $P=0.0318$, shRNA2; $P=0.00247 ; 48$ hours: Meis1 shRNA1; $P=0.0206$, shRNA2; $P=$ 0.0176; 72 hours: Meis1 shRNA1; $P=0.0260$, shRNA2; $P=0.0257 ; 96$ hours: Meis1 shRNA1; $P=0.0124$, shRNA2; $P=0.0200$, Figure 1(c), Figure 1(d)). If compromised Meis1 expression results in increased proliferation, cell cycle progression may be accelerated in Meis1 knockdown cells. Therefore, the cell cycle analysis was conducted. The results of this analysis demonstrated that the knockdown of Meis1 significantly decreased the percentage of cells in the $\mathrm{G}_{1}$ phase of the cell cycle in Meis1 repressed B9 and D3 cells (B9: Meis1 shRNA1; $P=0.00170$, shRNA2; $P=1.22 \mathrm{E}-05$, D3: Meis1 shRNA1; $P=3.23 \mathrm{E}-05$, shRNA2; $P=0.000531$, Figure 1 (e), Figure 1(f)). In addition, knockdown resulted in a significant increase in the percentage of cells in the $S$ phase of the cell cycle in Meis1 repressed B9 and D3 cells (B9: Meis1 shRNA1; $P=0.00526$, shRNA2; $P=0.000468$, D3: Meis1 shRNA1; $P=0.000465$, shRNA2; $P=0.00429$, Figure $1(\mathrm{e})$, Figure $1(\mathrm{f})$ ).

\subsection{SU11274 Suppresses the Proliferation of B9 and D3 Cells in the Presence of Meis1}

In order to test the effects of SU11274 on B9 and D3 cells, cell viability was determined using the XTT assay in the presence or absence of SU11274. The results showed no significant differences in the proliferation of B9 cells in the presence of Meis1 between the low-dose SU11274 treatment $(1 \mu \mathrm{M})$ and DMSO $(0.01 \%)$ treatment (Figure 2(a)). On the other hand, the low-dose treatment significantly decreased the proliferative rate of D3 cells $(P=0.0423$, Figure 2(b)). However, the high-dose treatment $(10 \mu \mathrm{M})$ significantly decreased the proliferative rate of B9 and D3 cells (B9: $P=0.0102$, D3: $P=0.0287$, Figure 2(a), Figure 2(b)). In contrast, even the high-dose SU11274 treatment did not have any significant effects on the proliferation of B9 and D3 cells in the absence of Meis1 (Figures 2(c)-(f)).

\subsection{Inhibition of c-Met Up-Regulates the Transcription of Genes Downstream of Meis1 and Meis1}

We then tested the effects of SU11274 on the transcription of genes downstream of Meis1 and Meis1 itself in B9 and D3 cells. Meis1 mRNA expression levels were significantly higher in B9 cells treated with the high dose of SU11274 than in those treated with the low dose or DMSO ( $P=0.00406$, Figure 3(a)). On the other hand, Meis1 mRNA expression levels were significantly higher in D3 cells treated with the low and high doses than in those treated with DMSO $(1 \mu \mathrm{M} ; P=1.01 \mathrm{E}-05,10 \mu \mathrm{M} ; P=6.35 \mathrm{E}-05$, Figure $3(\mathrm{~b}))$. These results indicate that SU11274 increases Meis1 transcription, suggesting the potential of c-Met to negatively regulate Meis1 transcription. Furthermore, we examined the mRNA levels of Hif1 $\alpha$ and Cdkn2a ( $p 16^{\text {Ink4a }}$ and $p 19^{\text {Arf }}$ ). The mRNA levels of Hif1 $\alpha$ and Cdkn2a ( $p 16^{\text {Ink4a }}$ and $p 19^{\text {Arf }}$ ) were significantly higher in B9 cells treated with the high dose of SU11274 than in those treated with the low dose or DMSO (Hif1 $\alpha: P=0.00119 ; p 16^{\text {Ink4a }}: P=0.00120 ; p 19^{\text {Arf }}$ : $P=0.0422$, Figure 3(a)). On the other hand, the mRNA levels of Hif1 $\alpha$ and Cdkn2a ( $p 16^{\text {Ink4a }}$ and $p 19^{\text {Arf }}$ ) were significantly higher in D3 cells treated with the low and high doses than in those treated with DMSO (1 $\mu$ M; Hif1 $\alpha: P=0.000595 ; p 16^{\text {Ink4a }}: P=1.12 \mathrm{E}-05 ; p 19^{\text {Arf }}: P=4.00 \mathrm{E}-06,10 \mu \mathrm{M} ;$ Hif $1 \alpha: P=0.00428 ; p 16^{\text {Ink } 4 a}: P=$ $0.00101 ; p 19^{A r f}: P=6.85 \mathrm{E}-05$, Figure 3(b)). These results suggest that SU11274 increases the transcription of Hif1 $\alpha$ and Cdkn2a ( $p 16^{\text {Ink4a }}$ and $p 19^{\text {Arf }}$ ), which may be mediated by Meis1 in B9 and D3 cells. In order to confirm this Meis1-dependent regulation, we measured the mRNA levels of Meis1, Hif1 $\alpha$, and Cdkn2a ( $p 16^{\text {Ink4a }}$ and $p 19^{\text {Arf }}$ ) in Meis1 knockdown B9 and D3 cells treated with SU11274. As expected, SU11274 did not have any effects on the transcription of Meis1 or Hif1 $\alpha$ in Meis1 repressed B9 and D3 cells (Figures 3(c)-(f)). However, Cdkn2a ( $p 16^{\text {Ink4a }}$ and $p 19^{\text {Arf }}$ ) mRNA expression levels were significantly higher in Meis1 knockdown B9 cells treated with the high dose than in those treated with the low dose or DMSO (Meis1 shRNA1; $p 16^{\text {Ink4a }}: P=$ 
(a) PSUPER

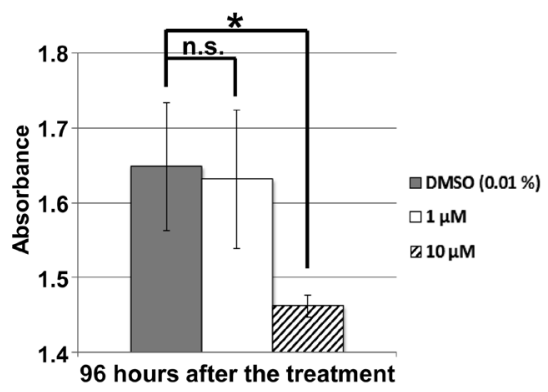

(c)

Meis1

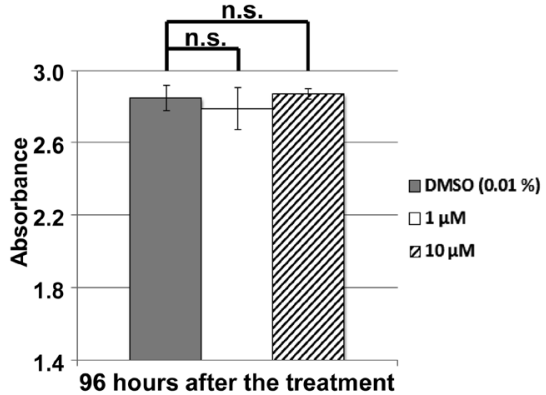

(e)

\section{Meis1}

\section{shRNA2}

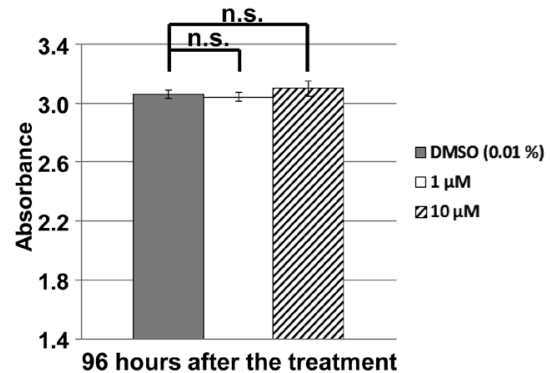

(b)

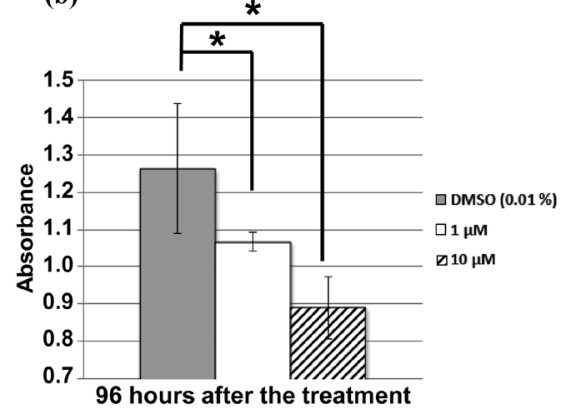

(d)

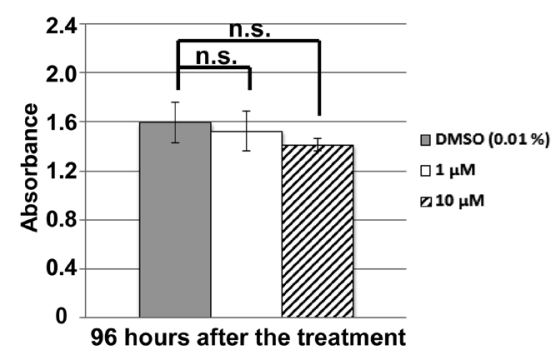

(f)

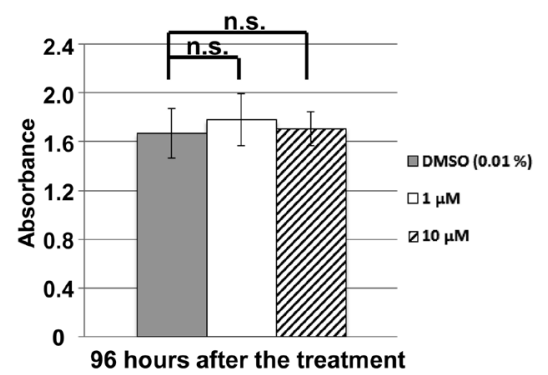

Figure 2. c-Met inhibition alters the proliferation of squamous cell carcinoma cells in the presence of Meis1. (a) B9 cells transduced with a control vector (pSUPER) were treated with DMSO (0.01\%) (gray), SU11274; $1 \mu \mathrm{M}$ (white) and $10 \mu \mathrm{M}$ (diagonal lined), and viability was then examinedusing the XTT assay. (b) D3 cells transduced with a control vector (pSUPER) were treated with DMSO (0.01\%) (gray), SU11274; $1 \mu \mathrm{M}$ (white) and $10 \mu \mathrm{M}$ (diagonal lined), and viability was then examinedusing the XTT assay. (c) B9 cells transduced with Meis1 shRNA1 were treated with DMSO (0.01\%) (gray), SU11274; $1 \mu \mathrm{M}$ (white) and $10 \mu \mathrm{M}$ (diagonal lined), and viability was then examinedusing the XTT assay. (d) D3 cells transduced with Meis1 shRNA1 were treated with DMSO (0.01\%) (gray), SU11274; $1 \mu \mathrm{M}$ (white) and $10 \mu \mathrm{M}$ (diagonal lined), and viability was then examinedusing the XTT assay. (e) B9 cells transduced with Meis1 shRNA2 were treated with DMSO (0.01\%) (gray), SU11274; $1 \mu \mathrm{M}$ (white) and $10 \mu \mathrm{M}$ (diagonal lined), and viability was then examinedusing the XTT assay. Absorbance at $450 \mathrm{~nm}$ was plotted. (f) D3 cells transduced with Meis1 shRNA2 were treated with DMSO (0.01\%) (gray), SU11274; $1 \mu \mathrm{M}$ (white) and $10 \mu \mathrm{M}$ (diagonal lined), and viability was then examinedusing the XTT assay. Absorbance at $450 \mathrm{~nm}$ was plotted. For all the graphs, experiments were performed in triplicate. The $P$-value was calculated by the $t$-test and displayed as the mean $\pm \mathrm{SD}, \mathrm{n}=3$. Error bars represent $\mathrm{SD} .{ }^{*}: P<0.05$, n.s., not significant.

0.0129; $p 19^{\text {Arf }}: P=0.0491$, Meis1 shRNA2; $p 16^{\text {Ink4a }}: P=0.0130 ; p 19^{\text {Arf }}: P=0.0114$, Figure 3(c), Figure 3(e)). On the other hand, Cdkn2a ( $p 16^{\text {Ink4a }}$ and $p 19^{\text {Arf }}$ ) mRNA expression levels were significantly higher in Meis1 knockdown D3 cells treated with the low and high doses than in those treated with the DMSO (Meis1 shRNA1; $1 \mu \mathrm{M} ; p 16^{\text {Ink4a }}: P=0.0104 ; p 19^{\text {Arf. }}: P=0.00434,10 \mu \mathrm{M} ; 16^{\text {Ink4a }}: P=0.00337 ; p 19^{\text {Arf }}: P=0.00161$, Meis1 
(a) PSUPER

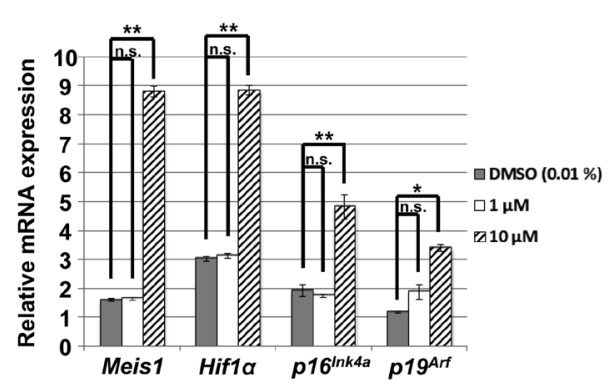

(c) $\begin{gathered}\text { Meis1 } \\ \text { shRNA1 }\end{gathered}$

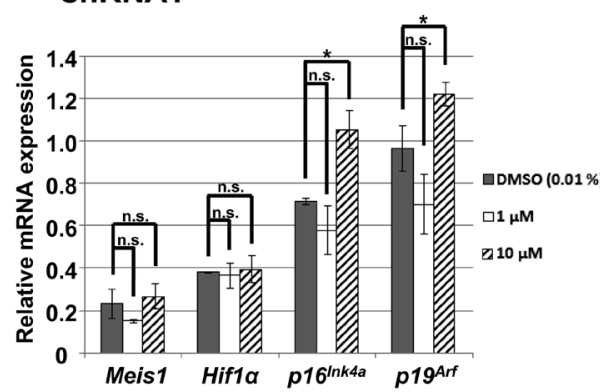

(e) Meis1

shRNA2

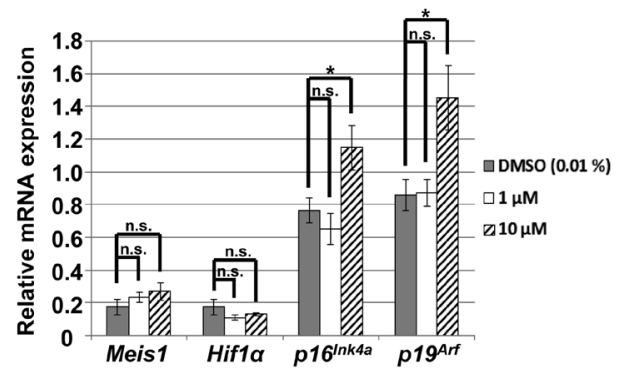

(b)

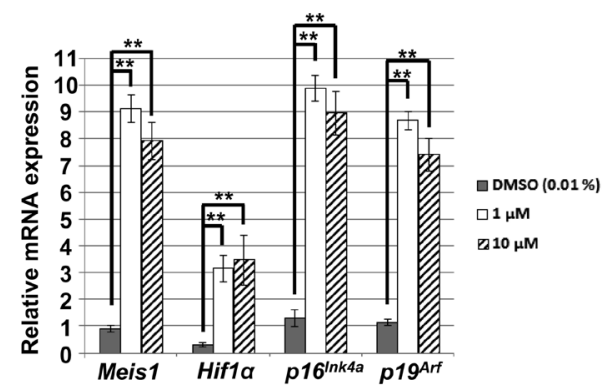

(d)

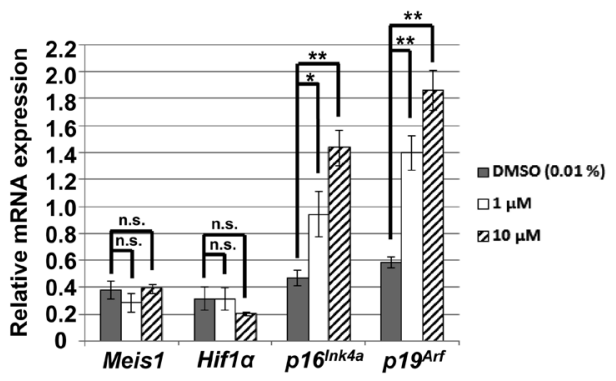

(f)

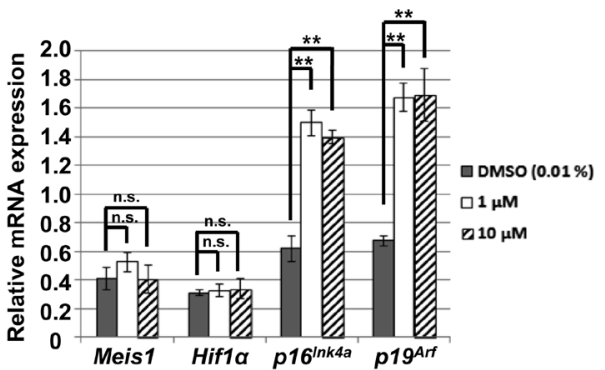

Figure 3. Inhibition of c-Met up-regulates the transcription of genesdownstream of Meis1 and Meis1. (a) B9 cells transduced with a control vector (pSUPER) were treated with DMSO (0.01\%) (gray), SU11274; $1 \mu \mathrm{M}$ (white) and $10 \mu \mathrm{M}$ (diagonal lined), and the relative mRNA levels of Meis1, Hif1 $\alpha, p 16^{I N K 4 a}$, and $p 19^{\text {Arf }}$ were examinedby qRT-PCR. (b) D3 cells transduced with a control vector (pSUPER) were treated with DMSO (0.01\%) (gray), SU11274; $1 \mu \mathrm{M}$ (white) and $10 \mu \mathrm{M}$ (diagonal lined), and the relative mRNA levels of Meis1, Hif1 $\alpha, p 16^{I N K 4 a}$, and $p 19^{\text {Arf }}$ were examinedby qRT-PCR. (c) B9 cells transduced with Meis1 shRNA1 were treated with DMSO (0.01\%) (gray), SU11274; $1 \mu \mathrm{M}$ (white) and $10 \mu \mathrm{M}$ (diagonal lined), and the relative mRNA levels of Meis 1 , Hif $1 \alpha, p 16^{I N K 4 a}$, and $p 19^{\text {Arf }}$ were then examinedby qRT-PCR. (d) D3 cells transduced with Meis1 shRNA1 were treated with DMSO (0.01\%) (gray), SU11274; $1 \mu \mathrm{M}$ (white) and $10 \mu \mathrm{M}$ (diagonal lined), and the relative mRNA levels of Meis1, Hif $1 \alpha, p 16^{I N K 4 a}$, and $p 19^{A r f}$ were then examinedby qRT-PCR. (e) B9 cells transduced with Meis1 shRNA2 were treated with DMSO (0.01\%) (gray), SU11274; $1 \mu \mathrm{M}$ (white) and $10 \mu \mathrm{M}$ (diagonal lined), and the relative mRNA levels of Meis1, Hif1 $\alpha, p 16^{I N K 4 a}$, and $p 19^{\text {Arf }}$ were then examinedby qRT-PCR. (f) D3 cells transduced with Meis1 shRNA2 were treated with DMSO (0.01\%) (gray), SU11274; $1 \mu \mathrm{M}$ (white) and $10 \mu \mathrm{M}$ (diagonal lined), and the relative mRNA levels of Meis1, Hif1 $\alpha, p 16^{I N K 4 a}$, and $p 19^{\text {Arf }}$ were then examinedby qRT-PCR. For all the graphs, experiments were performed in triplicate. The $P$-value was calculated by the $t$-test and displayed as the mean $\pm \mathrm{SD}, \mathrm{n}=3$. Error bars represent SD. ${ }^{* *}: P<0.01,{ }^{*}: P<0.05$.

shRNA2; $1 \mu \mathrm{M} ; p 16^{\text {Ink4a }}: P=0.000288 ; p 19^{\text {Arf }}: P=6.69 \mathrm{E}-05,10 \mu \mathrm{M} ; 16^{\text {Ink4a }}: P=0.000191 ; p 19^{\text {Arf. }}: P=$ 0.000707 , Figure 3(d), Figure 3(f). These results suggest that the transcriptional regulation of Hif1 $\alpha$ by Meis1 is tighter than that of Cdkn2a ( $p 16^{\text {Ink } 4 a}$ and $\left.p 19^{\text {Arf }}\right)$. 


\subsection{SU11274 Prevents Progression from the $G_{1}$ to $S$ Phase in $B 9$ and D3 Cells in the Presence of Meis 1}

If SU11274 suppresses cell proliferation, cell cycle progression may also be affected. In order to test this hypothesis, the cell cycle analysis was conducted on an equal number of control and Meis1 knockdown B9 and D3 cells in the presence and absence of SU11274. The results obtained demonstrated that the low dose of SU11274 treatment had very subtle effects on the cell cycle progression of B9 cells (Figure 4(a), Figure 4(b)). However, the percentage of cells in the $G_{0} / G_{1}$ phase of the cell cycle was significantly higher in B9 cells treated with the high dose of SU11274 than in those treated with the low dose of SU11274 or DMSO $(P=0.000596$, Figure 4(a), Figure 4(b)). In addition, the number of cells in the $S$ phase of the cell cycle was significantly lower in B9 cells treated with the high dose of SU11274 than in those treated with the low dose of SU11274 or DMSO ( $P=$ 0.0452, Figure 4(a), Figure 4(b)). On the other hand, the percentage of cells in the $G_{0} / G_{1}$ phase of the cell cycle was significantly higher in D3 cells treated with the low and high doses of than in those treated with the DMSO ( $1 \mu \mathrm{M} ; P=0.00151,10 \mu \mathrm{M} ; P=0.00327$, Figure 4(a), Figure 4(b)). In addition, the number of cells in the S phase of the cell cycle was significantly lower in D3 cells treated with the low and high doses than in those treated with DMSO ( $1 \mu \mathrm{M} ; P=0.000101,10 \mu \mathrm{M} ; P=0.000173$, Figure 4(a), Figure 4(b)). In contrast, the low and high doses of SU11274 had almost no effect on the percentage of cells in the $G_{0} / G_{1}$ and S phases of the cell cyclein Meis1 knockdown cells (Figures 4(c)-(f)). Under each condition, we also observed very negligible differences in the percentages of cells in the sub $G_{0} / G_{1}$ and $G_{2} / M$ phases of the cell cycle in Meis1 knockdown and control B9 and D3 cells treated and not treated with SU11274, respectively (Figures 4(c)-(f)). Taken together, these results indicate that SU11274 prevents progression from the $G_{1}$ to $S$ phase of the cell cycle, which is entirely Meis1-dependent.

\section{Discussion}

This study shows Meis1 is required for the c-Met inhibitor SU11274 to suppress the proliferation of the skin squamous cell carcinoma cell lines B9 and D3. SU11274 suppresses cell proliferation by modulating cell cycle progression in the presence of Meis1, but not in its absence (Figure 2(a)-(f), Figure 4(a)-(f)). It does so by activating the transcription of Meis1, which led to the transcription of Hif1 $\alpha$ and Cdkn2a ( $p 16^{\text {Ink4a }}$ and $\left.p 19^{A r f}\right)$ (Figure 3(a), Figure 3(b)). However, SU11274 did not increase the transcription of Hif1 $\alpha$ in Meis1 knockdown B9 and D3 cells, whereas it only increased the transcription of Cdkn2a (p16 Ink4a and $p 19^{\text {Arf }}$ (Figures 3(c)-(f)). These results suggest that SU11274 increases the transcription of Hif1 $\alpha$ and Cdkn2a (p16 ${ }^{\text {Ink4a }}$ and $p 19^{\text {Arf }}$ ) through the activation of Meis1, whereas the transcription of Cdkn2a $\left(p 16^{\text {Ink4a }}\right.$ and $\left.p 19^{A r f}\right)$ is regulated in Meis1-dependent and -independent manners (Figure 5).

The results of the cell cycle analysis indicated that cell cycle entry was significantly increased when Meis1 expression was compromised. This situation is similar to the alterations observed in epidermis, HSCs and cardiomyocytes with a Meis1 deficiency, indicating a role for Meis1 in the promotion of cell quiescence in order to suppress cell cycle entry [16] [18] [21]. As a transcriptional factor or co-regulator, Meis1 may affect the cell cycle machinery by promoting downstream gene expression. The regulation of proliferation by Meis1 may be due to its transcriptional targets. In the absence of $H i f 1 \alpha$, the cell cycle enters the growth phase from the $\mathrm{G}_{0}$ phase in LT-HSC [18]. In neonatal cardiomyocytes, Meis1 promotes the up-regulation of $p 16^{\operatorname{Ink} 4 a}$ and $p 19^{A r f}$ in order to limit proliferative potential [21]. Thus, it is reasonable to assume that similar mechanisms may also exist in skin squamous cancer cell lines.

Our previous study demonstrated Meis1 is required for epidermal tumorigenesis and regulates epidermal stem cells [16]. However, this study shows Meis1 down-regulates the proliferation of B9 and D3 cells. Apparent discrepancies between our previous and this study may be due to differences in study design. In our previous study, we knocked out Meis1 in the normal skin and benign tumors, papillomas instead of squamous cell carcinomas using Meis1 conditional knockout mice. Much less papillomas and squamous cell carcinomas were observed when we knocked down Meis1 in the normal skin and papillomas. In this study we knocked down Meis1 in squamous cell carcinoma cell lines. In vivo and in vitro situations are different as well as tumor stages are different. To compare these two experiments exactly, knocking out Meis1 in squamous cell carcinomas in vivo will be required.

A surprising finding was that the SU11274 activates Meis1 transcription. In the original idea, we expected SU11274 to downregulate Meis1 transcription, because SU11274 has been identified through candidate drug 
(a) pSUPER

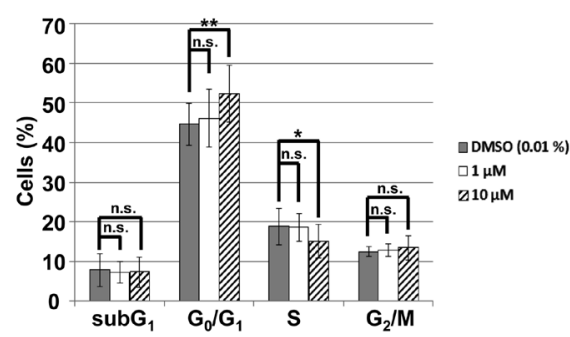

\section{Meis1}

(c) shRNA1

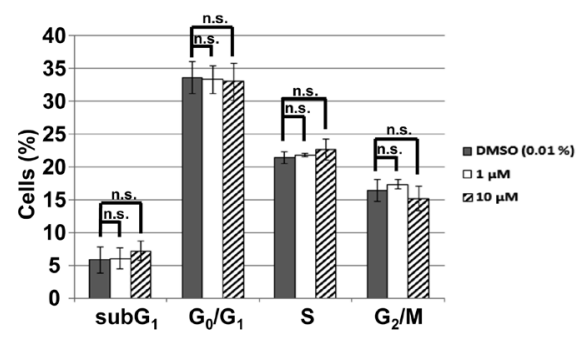

\section{Meis1}

(e) shRNA2

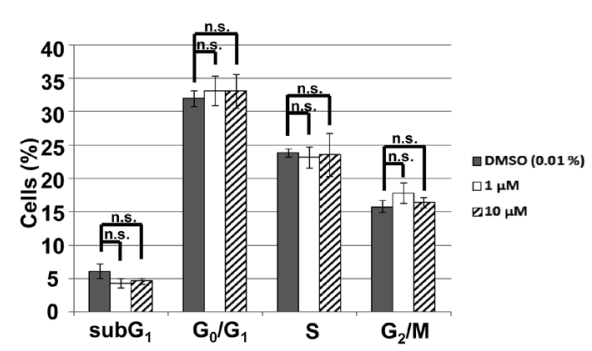

(b)

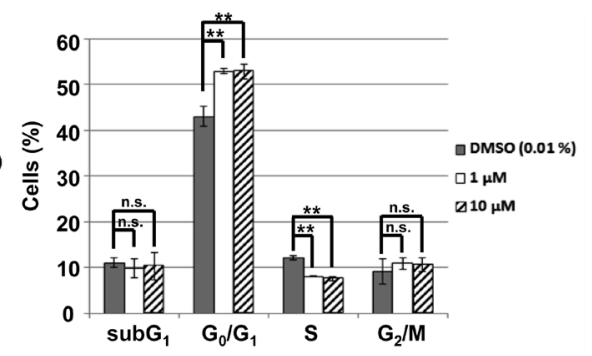

(d)

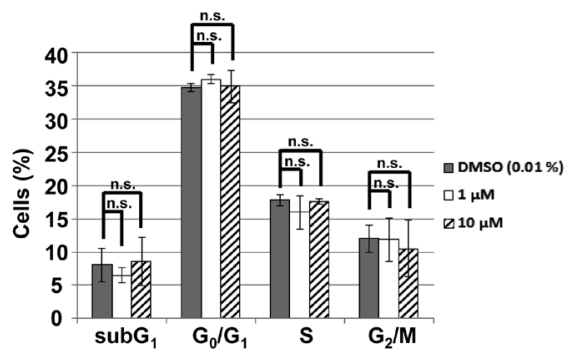

(f)

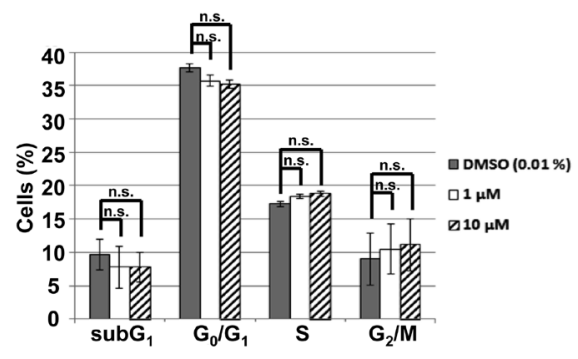

Figure 4. SU11274 prevents progression from the $\mathrm{G}_{1}$ to $\mathrm{S}$ phase in squamous cell carcinoma cells in the presence of Meis1. (a) B9 cells transduced with a control vector (pSUPER) were treated with DMSO (0.01\%) (gray), SU11274; $1 \mu$ M (white) and $10 \mu \mathrm{M}$ (diagonal lined), and the cell cycle analysis was then performedusing flow cytometry. (b) D3 cells transduced with a control vector (pSUPER) were treated with DMSO (0.01\%) (gray), SU11274; $1 \mu$ M (white) and $10 \mu$ M (diagonal lined), and the cell cycle analysis was then performedusing flow cytometry. (c) B9 cells transduced with Meis1 shRNA1 were treated with DMSO (0.01\%) (gray), SU11274; $1 \mu \mathrm{M}$ (white) and $10 \mu \mathrm{M}$ (diagonal lined), and the cell cycle analysis was then performed using flow cytometry. (d) D3 cells transduced with Meis1 shRNA1 were treated with DMSO (0.01\%) (gray), SU11274; $1 \mu \mathrm{M}$ (white) and $10 \mu \mathrm{M}$ (diagonal lined), and the cell cycle analysis was then performed using flow cytometry. (e) B9 cells transduced with Meis1 shRNA2 were treated with DMSO (0.01\%) (gray), SU11274; $1 \mu$ M (white) and $10 \mu \mathrm{M}$ (diagonal lined), and the cell cycle analysis was then performed using flow cytometry. (f) D3 cells transduced with Meis1 shRNA2 were treated with DMSO (0.01\%) (gray), SU11274; $1 \mu \mathrm{M}$ (white) and $10 \mu \mathrm{M}$ (diagonal lined), and the cell cycle analysis was then performed using flow cytometry. For all the graphs, experiments were performed in triplicate. The $P$-value was calculated for the percentage of cells by the $t$-test and displayed as the mean $\pm \mathrm{SD}, \mathrm{n}=3$. Error bars represent SD. ${ }^{*}: P<0.05$.

screening using Meis1/HoxA9-induced AML cell lines [30]. As expected, treatment with SU11274 suppressed the proliferation of B9 and D3 cells. However, contrary to expectations, SU11274 activated Meis1 transcription. In addition, the role of Meis1 in B9 and D3 cells has been found to be a growth suppressor rather than an oncogene in AML cell lines. These are probably because c-Met down-regulates Meis1 when it plays a role of a growth suppressor and up-regulates Meis1 when it plays that of an oncogene. Either way, SU11274 suppresses cell proliferation and Meis1 is a key molecule for the activity. 


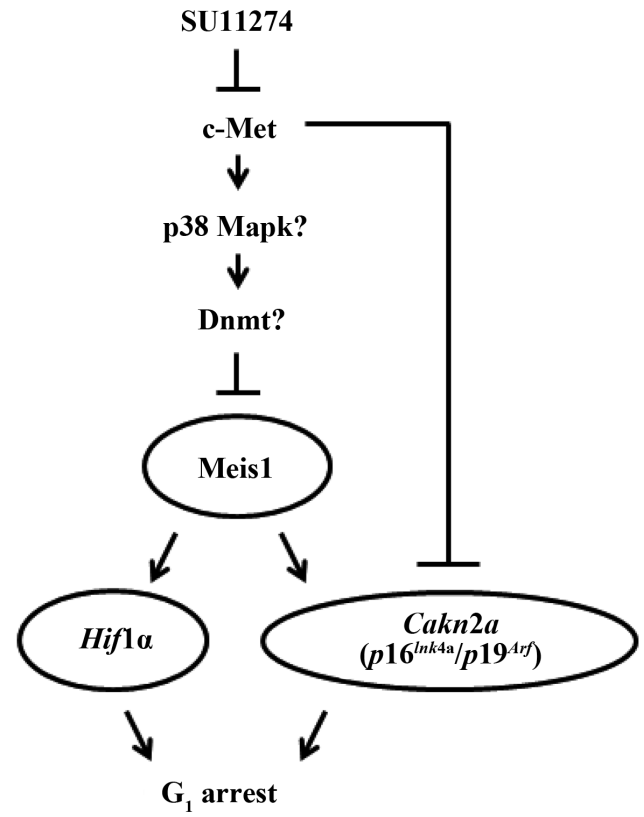

Figure 5. A schematic drawing of the regulation of gene expression mediated by Meis1 in skin squamous cell carcinoma cells.SU11274 inhibits c-Met. c-Met down-regulates the expression of Meis1 directly or indirectly. This might be mediated by p38Mapk induced Dnmt upregulation. Meis1 up-regulates the expression of Hif $1 \alpha, p 16^{I N K 4 a}$, and $p 19^{\text {Arf }}$. c-Met also down-regulates the expression of $p 16^{I N K 4 a}$ and $p 19^{A r f}$ in Meis1-independent and -dependent manners. Hif $1 \alpha, p 16^{I N K 4 a}$, and p19 Arf finally induce G1-arrest in B9 and D3 cells.

The molecular mechanisms underlying Meis1 down-regulation by c-Met have not been elucidated yet. HGF binding to the c-Met activates the PI3K and MAPK pathways [35]. Abnormal activation of these pathways either by overexpression of the ligand (HGF) or overexpression of mutation of the receptor (c-Met) is involved in various cancers causing increased cell proliferation, survival, and metastasis [31]-[33]. A recent study has also demonstrated that p38 MAPK down-regulates Fibulin 3 expression through hypermethylation of CpG sites in the regulatory sequences of the gene. Arechederra and colleagues reported that p38 MAPK stabilizes the DNA methylase, DNMT3A through HuR protein and increases protein levels of DNMT3A [36]. Although the clear mechanisms have not been elucidated, there is a possibility that similar mechanisms could exist in the downregulation of Meis1 (Figure 5). In other words, methylation status in the promoter region of Meis1 might be important for c-Met to downregulate Meis1. Methylation analysis and knockdown experiments of Dnmt could give us clear answers in the future.

\section{Conclusion}

In summary, we have shown that Meis1 is required for the c-Met inhibitor SU11274 to suppress the proliferation of the skin squamous cell carcinoma cell lines B9 and D3. We demonstrated a repressive role for Meis1 in regulating the proliferation of B9 and D3 cells through its modulation of cell cycle progression. The c-Met inhibitor SU11274 down-regulates the proliferation of B9 and D3 cells by activating Meis1 expression. Further investigation utilizing SU11274 or second generation c-Met inhibitors alone or in combination with standard-of-care therapies may improve its efficacy in the treatment of squamous cell carcinomas.

\section{Acknowledgements}

This work was supported by Grants-in-Aid (15K08438) for Scientific Research from the Ministry of Education, Culture, Sports, Science, and Technology of Japan.

\section{Author's Contribution}

The authors declare no conflict of interest associated with this manuscript. 


\section{References}

[1] Moskow, J.J., Bullrich, F., Huebner, K., Daar, I.O. and Buchberg, A.M. (1995) Meis1, a PBX1-Related Homeobox Gene Involved in Myeloid Leukemia in BXH-2 Mice. Molecular and Cellular Biology, 10, 5434-5443. http://dx.doi.org/10.1128/MCB.15.10.5434

[2] Steelman, S., Moskow, J.J., Muzynski, K., North, C., Druck, T., Montgomery, J.C., Huebner, K., Daar, I.O. and Buchberg, A.M. (1997) Identification of a Conserved Family of Meis1-Related Homeobox Genes. Genome Research, 2, 142-156. http://dx.doi.org/10.1101/gr.7.2.142

[3] Thorsteinsdottir, U., Kroon, E., Jerome, L., Blasi, F. and Sauvageau, G. (2001) Defining Roles for HOX and MEIS1 Genes in Induction of Acute Myeloid Leukemia. Molecular and Cellular Biology, 1, 224-234.

http://dx.doi.org/10.1128/MCB.21.1.224-234.2001

[4] Mann, R.S. and Affolter, M. (1998) Hox Proteins Meet More Partners. Current Opinion in Genetics \& Development, 4, 423-429. http://dx.doi.org/10.1016/S0959-437X(98)80113-5

[5] Rozovskaia, T., Feinstein, E., Mor, O., Foa, R., Blechman, J., Nakamura, T., Croce, C.M., Cimino, G. and Canaani, E. (2001) Upregulation of Meis1 and HoxA9 in Acute Lymphocytic Leukemias with the t (4: 11) Abnormality. Oncogene, 7, 874-878. http://dx.doi.org/10.1038/sj.onc.1204174

[6] Bullinger, L., Döhner, K., Bair, E., Fröhling, S., Schlenk, R.F., Tibshirani, R., Döhner, H. and Pollack, J.R. (2004) Use of Gene-Expression Profiling to Identify Prognostic Subclasses in Adult Acute Myeloid Leukemia. New England Journal of Medicine, 16, 1605-1616. http://dx.doi.org/10.1056/NEJMoa031046

[7] Dickson, G.J., Liberante, F.G., Kettyle, L.M., O’Hagan, K.A., Finnegan, D.P., Bullinger, L., Geerts, D., McMullin, M.F., Lappin, T.R., Mills, K.I. and Thompson, A. (2013) HOXA/PBX3 Knockdown Impairs Growth and Sensitizes Cytogenetically Normal Acute Myeloid Leukemia Cells to Chemotherapy. Haematologica, 8, 1216-1225. http://dx.doi.org/10.3324/haematol.2012.079012

[8] Grubach, L., Juhl-Christensen, C., Rethmeier, A., Olesen, L.H., Aggerholm, A., Hokland, P. and Ostergaard, M. (2008) Gene Expression Profiling of Polycomb, Hox and Meis Genes in Patients with Acute Myeloid Leukaemia. European Journal of Haematology, 2, 112-122. http://dx.doi.org/10.1111/j.1600-0609.2008.01083.x

[9] Zangenberg, M., Grubach, L., Aggerholm, A., Silkjaer, T., Juhl-Christensen, C., Nyvold, C.G., Kjeldsen, E., Ommen, H.B. and Hokland, P. (2009) The Combined Expression of HOXA4 and MEIS1 Is an Independent Prognostic Factor in Patients with AML. European Journal of Haematology, 5, 439-448. http://dx.doi.org/10.1111/j.1600-0609.2009.01309.x

[10] Fernandez, P., Carretero, J., Medina, P.P., Jimenez, A.I., Rodriguez-Perales, S., Paz, M.F., Cigudosa, J.C., Esteller, M., Lombardia, L., Morente, M., Sanchez-Verde, L., Sotelo, T. and Sanchez-Cespedes, M. (2004) Distinctive Gene Expression of Human Lung Adenocarcinomas Carrying LKB1 Mutations. Oncogene, 23, 5084-5091. http://dx.doi.org/10.1038/sj.onc.1207665

[11] Geerts, D., Revet, I., Jorritsma, G., Schilderink, N. and Versteeg, R. (2005) MEIS Homeobox Genes in Neuroblastoma. Cancer Letters, 228, 43-50. http://dx.doi.org/10.1016/j.canlet.2005.01.047

[12] Jones, T.A., Flomen, R.H., Senger, G., Nizetić, D. and Sheer, D. (2000) The Homeobox Gene MEIS1 Is Amplified in IMR-32 and Highly Expressed in Other Neuroblastoma Cell Lines. European Journal of Cancer, 36, 2368-2374. http://dx.doi.org/10.1016/S0959-8049(00)00332-4

[13] Spieker, N., van Sluis, P., Beitsma, M., Boon, K., van Schaik, B.D., van Kampen, A.H., Caron, H. and Versteeg, R. (2001) The MEIS1 Oncogene Is Highly Expressed in Neuroblastoma and Amplified in Cell Line IMR32. Genomics, 71, 214-221. http://dx.doi.org/10.1006/geno.2000.6408

[14] Crijns, A.P., de Graeff, P., Geerts, D., Ten Hoor, K.A., Hollema, H., van der Sluis, T., Hofstra, R.M., de Bock, G.H., de Jong, S., van der Zee, A.G. and de Vries, E.G. (2007) MEIS and PBX Homeobox Proteins in Ovarian Cancer. European Journal of Cancer, 43, 2495-2505. http://dx.doi.org/10.1016/j.ejca.2007.08.025

[15] Dekel, B., Metsuyanim, S., Schmidt-Ott, K.M., Fridman, E., Jacob-Hirsch, J., Simon, A., Pinthus, J., Mor, Y., Barasch, J., Amariglio, N., Reisner, Y., Kaminski, N. and Rechavi, G. (2006) Multiple Imprinted and Stemness Genes Provide a Link between Normal and Tumor Progenitor Cells of the Developing Human Kidney. Cancer Research, 66, 6040-6049. http://dx.doi.org/10.1158/0008-5472.CAN-05-4528

[16] Okumura, K., Saito, M., Isogai, E., Aoto, Y., Hachiya, T., Sakakibara, Y., Katsuragi, Y., Hirose, S., Kominami, R, Goitsuka, R, Nakamura, T. and Wakabayashi, Y. (2014) Meis1 Regulates Epidermal Stem Cells and Is Required for Skin Tumorigenesis. PLoS ONE, 7, e102111. http://dx.doi.org/10.1371/journal.pone.0102111

[17] Hisa, T., Spence, S.E., Rachel, R.A., Fujita, M., Nakamura, T., Ward, J.M., Devor-Henneman, D.E., Saiki, Y., Kutsuna, H., Tessarollo, L., Jenkins, N.A. and Copeland, N.G. (2004) Hematopoietic, Angiogenic and Eye Defects in Meis1 Mutant Animals. EMBO Journal, 23, 450-459. http://dx.doi.org/10.1038/sj.emboj.7600038

[18] Mahmoud, A.I., Kocabas, F., Muralidhar, S.A., Kimura, W., Koura, A.S., Thet, S., Porrello, E.R. and Sadek, H.A. 
(2013) Meis1 Regulates Postnatal Cardiomyocyte Cell Cycle Arrest. Nature, 7448, 249-253. http://dx.doi.org/10.1038/nature12054

[19] Li, W.H., Kai, H.A., Guo, H.Z. and Cui, G.H. (2014) Meis1 Regulates Proliferation of Non-Small-Cell Lung Cancer Cells. Journal of Thoracic Disease, 6, 850-855.

[20] Hirayama, T, Asano, Y, Iida, H., Watanabe, T., Nakamura, T. and Goitsuka, R. (2014) Meis1 Is Required for the Maintenance of Postnatal Thymic Epithelial Cells. PLoS ONE, 9, e89885. http://dx.doi.org/10.1371/journal.pone.0089885

[21] Simsek, T., Kocabas, F., Zheng, J., Deberardinis, R.J., Mahmoud, A.I., Olson, E.N., Schneider, J.W., Zhang, C.C. and Sadek, H.A. (2010) The Distinct Metabolic Profile of Hematopoietic Stem Cells Reflects Their Location in a Hypoxic Niche. Cell Stem Cell, 3, 380-390. http://dx.doi.org/10.1016/j.stem.2010.07.011

[22] Takubo, K., Goda, N., Yamada, W., Iriuchishima, H., Ikeda, E., Kubota, Y., Shima, H., Johnson, R.S., Hirao, A., Suematsu, M. and Suda, T. (2010) Regulation of the HIF-1Alpha Level Is Essential for Hematopoietic Stem Cells. Cell Stem Cell, 3, 391-402. http://dx.doi.org/10.1016/j.stem.2010.06.020

[23] Kocabas, F., Zheng, J., Thet, S., Copeland, N.G., Jenkins, N.A., DeBerardinis, R.J., Zhang, C. and Sadek, H.A. (2012) Meis1 Regulates the Metabolic Phenotype and Oxidant Defense of Hematopoietic Stem Cells. Blood, 25, 4963-4972. http://dx.doi.org/10.1182/blood-2012-05-432260

[24] Ergen, A.V. and Goodell, M.A. (2010) Mechanisms of Hematopoietic Stem Cell Aging. Experimental Gerontology, 4, 286-290. http://dx.doi.org/10.1016/j.exger.2009.12.010

[25] Sherr, C.J. (2006) Divorcing ARF and p53: An Unsettled Case. Nature Reviews Cancer, 9, 663-673. http://dx.doi.org/10.1038/nrc1954

[26] Kamijo, T., Weber, J.D., Zambetti, G., Zindy, F., Roussel, M.F. and Sherr, C.J. (1998) Functional and Physical Interactions of the ARF Tumor Suppressor with p53 and Mdm2. Proceedings of the National Academy of Sciences of the United States of America, 14, 8292-8297. http://dx.doi.org/10.1073/pnas.95.14.8292

[27] Kelly-Spratt, K.S., Gurley, K.E., Yasui, Y. and Kemp, C.J. (2004) p19 Arf Suppresses Growth, Progression, and Metastasis of Hras-Driven Carcinomas through p53-Dependent and -Independent Pathways. PLoS Biology, 8, e242. http://dx.doi.org/10.1371/journal.pbio.0020242

[28] Takeuchi, S., Takahashi, A., Motoi, N., Yoshimoto, S., Tajima, T., Yamakoshi, K., Hirao, A., Yanagi, S., Fukami, K., Ishikawa, Y., Sone, S., Hara, E. and Ohtani, N. (2010) Intrinsic Cooperation between p16 $6^{\text {INK4a }}$ and p21 Waf1/Cip1 in the Onset of Cellular Senescence and Tumor Suppression in Vivo. Cancer Research, 22, 9381-9390. http://dx.doi.org/10.1158/0008-5472.CAN-10-0801

[29] Wang, X., Le, P., Liang, C., Chan, J., Kiewlich, D., Miller, T., Harris, D., Sun, L., Rice, A., Vasile, S., Blake, R.A., Howlett, A.R., Patel, N., McMahon, G. and Lipson, K.E. (2003) Potent and Selective Inhibitors of the Met [Hepatocyte Growth Factor/Scatter Factor (HGF/SF) Receptor] Tyrosine Kinase Block HGF/SF-Induced Tumor Cell Growth and Invasion. Molecular Cancer Therapeutics, 2, 1085-1092.

[30] Mulgrew, N.M., Kettyle, L.M., Ramsey, J.M., Cull, S., Smyth, L.J., Mervyn, D.M., Bijl, J.J. and Thompson, A. (2014) c-Met Inhibition in a HOXA9/Meis1 Model of CN-AML. Developmental Dynamics, 1, 172-181. http://dx.doi.org/10.1002/dvdy.24070

[31] Huang, P.H., Mukasa, A., Bonavia, R., Flynn, R.A., Brewer, Z.E., Cavenee, W.K., Furnari, F.B. and White, F.M. (2007) Quantitative Analysis of EGFRvIII Cellular Signaling Networks Reveals a Combinatorial Therapeutic Strategy for Glioblastoma. Proceedings of the National Academy of Sciences of the United States of America, 31, 12867-12872. http://dx.doi.org/10.1073/pnas.0705158104

[32] Ma, P.C., Tretiakova, M.S., Nallasura, V., Jagadeeswaran, R., Husain, A.N. and Salgia, R. (2007) Downstream Signalling and Specific Inhibition of c-MET/HGF Pathway in Small Cell Lung Cancer: Implications for Tumour Invasion. British Journal of Cancer, 3, 368-377. http://dx.doi.org/10.1038/sj.bjc.6603884

[33] Kenessey, I., Keszthelyi, M., Krámer, Z., Berta, J., Adám, A., Dobos, J., Mildner, M., Flachner, B., Cseh, S., Barna, G., Szokol, B., Orfi, L., Kéri, G., Döme, B., Klepetko, W., Tímár, J. and Tóvári, J. (2010) Inhibition of c-Met with the Specific Small Molecule Tyrosine Kinase Inhibitor SU11274 Decreases Growth and Metastasis Formation of Experimental Human Melanoma. Current Cancer Drug Targets, 3, 332-342. http://dx.doi.org/10.2174/156800910791190184

[34] Wong, P., Iwasaki, M., Somervaille, T.C., So, C.W. and Cleary, M.L. (2007) Meis1 Is an Essential and Rate-Limiting Regulator of MLL Leukemia Stem Cell Potential. Genes \& Development, 21, 2762-2774. http://dx.doi.org/10.1101/gad.1602107

[35] Eder, J.P., Vande Woude, G.F., Boerner, S.A. and LoRusso, P.M. (2009) Novel Therapeutic Inhibitors of the c-Met Signaling Pathway in Cancer. Clinical Cancer Research, 15, 2207-2214. http://dx.doi.org/10.1158/1078-0432.CCR-08-1306 
[36] Arechederra, M., Priego, N., Vázquez-Carballo, A., Sequera, C., Gutiérrez-Uzquiza, Á., Cerezo-Guisado, M.I., Ortiz-Rivero, S., Roncero, C., Cuenda, A., Guerrero, C. and Porras, A. (2015) p38 MAPK Down-Regulates Fibulin 3 Expression through Methylation of Gene Regulatory Sequences: Role in Migration and Invasion. The Journal of Biological Chemistry, 290, 4383-4397. http://dx.doi.org/10.1074/jbc.M114.582239

\section{Submit or recommend next manuscript to SCIRP and we will provide best service for you:}

Accepting pre-submission inquiries through Email, Facebook, Linkedin, Twitter, etc A wide selection of journals (inclusive of 9 subjects, more than 200 journals)

Providing a 24-hour high-quality service

User-friendly online submission system

Fair and swift peer-review system

Efficient typesetting and proofreading procedure

Display of the result of downloads and visits, as well as the number of cited articles

Maximum dissemination of your research work

Submit your manuscript at: http://papersubmission.scirp.org/ 